\title{
Research on Money Laundering Risk Analysis and Legal Supervision of Third Party Payment
}

\author{
Ni Xue \\ Hainan Vocational College of Political Science and Law, Hainan, Haikou, 571100
}

Key words: third party payment business; money laundering risk; legal supervision

\begin{abstract}
In the increasingly extensive use of Internet technology, the Internet has become part of people's production and life, such as online shopping, which to a large extent to promote the development of e-commerce, the resulting third-party payment business scale Continue to expand, the number of user groups continue to increase. This also makes third-party payment business there is a greater risk of money laundering risk. This will have a greater negative impact on the development of third party payment business and the development of third party payment enterprises. Based on this, this article will be based on third-party payment business, the third-party payment business may exist in the risk of money laundering in detail, and then put forward some legal regulatory recommendations, hoping to reduce the third party payment business money laundering risk help.

Compared with the financial institutions will be a rigorous review of the customer, third-party payment business more emphasis on the user's personal information and online transaction information protection, which makes the criminals in recent years has been transferred to third-party payment channels to third-party payment platform, Payment model innovation, the corresponding regulatory system and means are not sound and effective, resulting in criminals use third-party payment platform for the possibility of high money laundering. This is for the third party to pay business and business development is very unfavorable, and even bear the legal responsibility for this. In order to avoid the recurrence of such a situation, care should be taken to strengthen the legal supervision of third parties' payments, not to create opportunities for criminals, and to kill money laundering in the cradle. In view of this, it is necessary to continue to strengthen the legal supervision of third party payment business.
\end{abstract}

\section{First, third party payment business}

E-commerce operation model and business process of the third link, information flow, capital flow, logistics is the key to the development of e-commerce. Among them, the flow of funds to the convenience of payment made a request, which third-party payment business came into being. With the recent expansion of e-commerce operations, third-party payment business has also been greatly affected, the transaction more frequent, the scale continues to expand. In fact, the so-called third-party payment business, is the use of the Internet to quickly send a payment order to pay the business.

From the perspective of the flow of funds, the third party payment business is mainly for the enterprise and the seller services, through the integration of many bank card payment, the most convenient way to pay presented in the seller and the buyer in front of the two sides to facilitate transactions. This also fully illustrates the value of third-party payment business, namely: third-party payment business for the bank integrated retail e-commerce settlement business, making 
the bank in the consumption of very little marketing costs, to a large extent to promote e-commerce Settlement business promotion. At the same time, the implementation of third-party payment business, but also significantly reduce the amount of money allocated funds, greatly reducing the settlement costs.

In the face of the actual situation of the current third party payment business operation, it is determined that the third party payment business is equivalent to the bank settlement business, especially the third party payment enterprise in the bank to open the account as the general intermediary of the payment account. Which makes the third party payment business is equivalent to the bank e-commerce aspects of the settlement business. Therefore, it is true that third party payment business is involved in the bank's intermediary business.

\section{Second, the risk of money laundering exists in third party payment business}

For the third party payment business, in the specific operation of the process there is a greater risk, especially the risk of money laundering, if it really involves the risk of money laundering, then not only economic losses, there may be criminal responsibility. Therefore, it is necessary to correctly understand the possible risk of money laundering in third party payment business and to strengthen legal supervision. Refer to the relevant information and analysis of the operation of third-party payment business to determine the third-party payment business may exist the risk of money laundering is:

China's third-party payment is still in the market development stage, a variety of business models are constantly innovating, such as online payment, the issuance of electronic money, bank and bill inter-bank settlement. In the third-party payment business model innovation at the same time, the corresponding regulatory system and regulatory means should also keep pace with the times, so that it can strictly and cautiously supervise the operation of third-party payment business, so you can guarantee that third-party payment business Good operation, reduce the risk of money laundering, but the actual situation is not the case. Third-party payment companies tend to focus on third-party payment model innovation, while ignoring the regulatory system and regulatory means, leading to regulatory work is lagging behind, can not be on the ever-changing third-party payment business to be strict, reasonable and effective Of the regulation, so even if the third party payment problems or defects can not be found in time, then it is likely to create opportunities for lawless elements, with technical means to use third-party payment for money laundering. In addition, the previous regulatory compliance has been unable to keep up with the pace of development of third parties, while consuming regulatory resources at the same time there is a low sensitivity, can not effectively monitor the risk of money laundering.

With the increasing use of Internet technology, which makes e-commerce is more and more Internet users know and use, shopping. The corresponding third-party payment platform has accumulated a large number of user groups, to Alipay, in its development of six years has accumulated more than 300 million registered users. Which to some extent to promote the development of third-party payment business, but also to third-party payment business to bring greater risk of money laundering. The reason why this is because the third party to pay business services only need to register and log in, that is, the operation of third-party payment, coupled with the use of encryption technology to maximize the protection of the user's information, but also to the lawless elements to create The opportunity to money laundering, that is, criminals use encryption technology to make their own information is well protected features, the establishment of false accounts, log on third-party payment platform, and then money laundering.

Different from the financial institutions need to audit the identity of the customer, third-party 
payment business is more of the user's personal information and payment information to keep confidential, to avoid user information leakage. This gives the customer identification and business legitimacy audit to bring some difficulty, easy to be money-laundering use. That is, lawless elements to use third-party payment platform for money laundering, not only through the bank, but also because of online payment behavior is more subtle and money laundering behavior is not leaked out. It is precisely because of this, many lawless elements have been transferred to third-party money-laundering channels to pay business.

\section{Third, to strengthen the third party payment business legal advice}

In view of the current third party payment business prone to money laundering risk situation, should pay attention to strengthen the legal supervision. I refer to the relevant information, this aspect of a detailed analysis and research, made the following recommendations, namely:

In order to avoid the risk of money laundering in the current third party payment business, we should actively establish a real-time risk supervision index system and conduct a rigorous, comprehensive and detailed analysis of all transaction information handled by the organization to determine the risky areas and strengthen supervision In order to detect the risk of money laundering in a timely manner and to control the risk of money laundering in a timely manner. For the implementation of the risk control index system should focus on the existence of third-party payment platform for the existence of the regulation of money-laundering weak links; to strengthen the risk assessment in order to grasp the third party payment business risk factors may exist, strengthen the third party payment business control The

For the current criminals may establish a virtual account, the use of third-party payment platform for money laundering situation, but also pay attention to strengthening customer identification, that is, to strengthen the ability to identify a variety of customer identification and related mechanisms in the customer account registration and account registration The identity of the customer to identify and identify, in order to prevent criminals. In addition, the use of a private key on a third-party payment platform to master customer identity information to avoid money laundering risk.

\section{Concluding remarks:}

Based on a series of analyzes in this paper, it is determined that the risk of money laundering is increasing in the case of the expansion of the third party payment business in recent years. The reason why this is said, because the regulatory means lag, increasing the difficulty of customer identification, online payment behavior with a higher degree of concealment may induce the risk of money laundering. In view of this situation, the author proposes to establish real-time risk supervision index system, strengthen customer identification, etc., so as to effectively avoid the risk of money laundering.

\section{Acknowledgment}

2016 National Social Science Fund Project: 16BFX130, “Internet Financial Market Access and Risk Legal Supervision Research”.

2015 Social Science and Social Sciences of Hainan Province Social Science Planning Project: HNSK (QN) 15-46, "International Tourism Island vision under the network financial regulatory legal mechanism”. 


\section{References:}

[1] Fan Ruqian, Shi Yuzhou, Ye Qing, etc. Third-party payment business money laundering risk analysis and regulatory recommendations [J]. Shanghai Finance, 2012, (5): 46-49.

[2] Wei Wei. Using third-party payment platform for money laundering research [D]. South China University for Nationalities, 2014.

[3] Liu Weiyun.Three-party payment business exists money laundering risk and countermeasures [J]. Modern business, 2011, (27): 32-32,31.

[4] Cao Xiuxian, Wang Chongjian, Wu Miao, etc .. On the third party payment of money laundering risk and fund monitoring recommendations [J]. Gansu Finance, 2014, (9): 53-54.

[5] To Wenqing. Third-party payment of the risk and its prevention research [D]. Tianjin University of Commerce, 2015.

[6] Li Lijuanzi. Third party payment business risk prevention legal issues [D]. Hunan University, 2012. 